\title{
PELORIBATES ROYNORTONI (ACARI, ORIBATIDA, HAPLOZETIDAE), A NEW SPECIES OF ORIBATID MITES FROM THE USA
}

\author{
Sergey G. Ermilovi ${ }^{*}$ Umukusum Ya. Shtanchaeva ${ }^{2}$ and Luis S. Subías ${ }^{2}$ \\ ${ }^{1}$ Institute of Environmental and Agricultural Biology (X-BIO), Tyumen State University, \\ Tyumen, Russia \\ ${ }^{2}$ Complutense University, Madrid, Spain \\ *corresponding author; e-mail: ermilovacari@yandex.ru
}

\begin{abstract}
A new species of the genus Peloribates (Oribatida, Haplozetidae) is described from Louisiana, USA. Peloribates roynortoni Ermilov, Shtanchaeva et Subías sp.n. is tentatively included in the subgenus Peloribates (Peloribatodes). The new species differs from Peloribates (Peloribatodes) incompatibilis Mahunka, 2011 by the presence of prolamellae, macrofoveolate prodorsum, notogaster and anogenital region as well as striate epimeres.
\end{abstract}

KEY WORDS: Oribatid mites, systematics, morphology, USA.

DOI: 10.21684/0132-8077-2019-27-1-3-9

\section{INTRODUCTION}

The oribatid mite genus Peloribates (Acari, Oribatida, Haplozetidae) was proposed by Berlese (1908) with Oribata peloptoides Berlese, 1888 as type species. According to Subías's catalogue (2019), this genus comprises 92 known species, characterized by a cosmopolitan distribution, and four subgenera: P. (Peloribates) Berlese, 1908 (89 species); P. (Aokibates) Mahunka, 1988 (1 species); P. (Peloribatodes) Mahunka, 2011 (1 species); and P. (Tentaculozetes) Balogh, 1970 (1 species).

In the course of the taxonomic identification of oribatid mites from the USA (Louisiana), we found a new species of Peloribates. The main goal of our paper is to describe and illustrate this new species.

At present, 16 species of Peloribates are registered in the USA(Marshall et al. 1987; Subías 2019).

\section{METHODS}

Specimens were mounted in lactic acid on temporary cavity slides for measurement and illustration. Body length was measured in lateral view, from the tip of the rostrum to the posterior edge of the notogaster. Notogastral width refers to the maximum width of the notogaster in dorsal view. Lengths of body setae were measured in lateral aspect. All body measurements are presented in micrometers $(\mu \mathrm{m})$. The formulas for leg setation are provided in parentheses according to the sequence trochanter-femur-genu-tibia-tarsus (famulus included). Formulas for leg solenidia are given in square brackets according to the sequence genu-tibia-tarsus.

Drawings were made with a camera lucida using a Leica transmission light microscope "Lei- ca DM 2500". Images were obtained with an AxioCam ICc3 camera using a Carl Zeiss transmission light microscope "Axio Lab.A1".

Morphological terminology used in this paper follows that of F. Grandjean: see Travé and Vachon (1975) for references, Norton (1977) for leg setal nomenclature, and Norton and Behan-Pelletier (2009) for overview.

The following abbreviations are used: irtinner rostral tooth; lam-lamella; plam - prolamella; slam - sublamella; $A l$-sublamellar porose area; $t u$ - tutorium; ro, le, in, $b s$, ex-rostral, lamellar, interlamellar, bothridial and exobothridial setae, respectively; $b o$ - bothridium; $l r p$ lateral ridge of prodorsum; $A d$-sejugal porose area; $D$-dorsophragma; $P$ - pleurophragma; $c$, $d a, d m, d p, l a, l m, l p, h, p$-notogastral setae; $S a, S 1, S 2, S 3$-notogastral saccules; ia, im, ip, ih, ips-notogastral lyrifissures; gla-opisthonotal gland opening; $h, m, a-$ subcapitular setae; or-adoral seta; $v, l, d, c m, a c m, u l, s u l, v t$, lt - palp setae; $\omega$-palp and leg solenidion; cha, chb - cheliceral setae; $T g$ - Trägårdh's organ; $I$, $I I$ - pedotecta I, II, respectively; $1 a, 1 b, 1 c, 2 a$, $3 a, 3 b, 3 c, 4 a, 4 b$-epimeral setae; ap 2, apsj, ap 3 -apodeme 2, sejugal apodeme, apodeme 3 , respectively; dis-discidium; $c p$-circumpedal carina; $g, a g, a n, a d$ - genital, aggenital, anal and adanal setae, respectively; iad-adanal lyrifissure; Amar - marginal porose area; p.o.-preanal organ; $\mathrm{Tr}, \mathrm{Fe}, \mathrm{Ge}, \mathrm{Ti}, \mathrm{Ta}-\mathrm{leg}$ trochanter, femur, genu, tibia, tarsus, respectively; $t$ - tooth; p.a.-leg porose area; $\sigma, \varphi$ - leg solenidia; $\varepsilon$ - leg famulus; $v, e v, b v, l, d, f t, t c, i t, p, u, a, s, p v-\mathrm{leg}$ setae. 




Figs. 1-3. Peloribates roynortoni Ermilov, Shtanchaeva et Subías sp.n., adult: 1-dorsal view; 2-posterior part of body, lateral view; 3 - anterior part of body (gnathosoma and legs not shown), lateral view. Scale bar=50 $\mu \mathrm{m}$.

\section{SYSTEMATICS}

\section{Superfamily Oripodoidea}

Family Haplozetidae

Genus Peloribares Berlese, 1908

Type species: Oribata peloptoides Berlese, 1888

\section{Peloribates roynortoni Ermilov, Shtanchaeva et Subías sp.n.}

(Figs. 1-20)

Diagnosis. Body size: $232-249 \times 149-182$. Prodorsum, notogaster and anogenital region with macrofoveoles; epimeres with longitudinal stria. Rostrum narrowly rounded. Prolamellae present, long. Rostral, lamellar and interlamellar setae well-developed, setiform, barbed. Bothridial setae long, clavate, with shortly ciliate head. Anterior notogastral margin protruding medially. Notogastral setae of medium size, setiform, barbed. Epimeral and anogenital setae short, setiform, slightly barbed.

Description. Measurements. Very small species. Body length: 249 (holotype, male), 232-249 (six paratypes, four females and two males); notogaster width: 166 (holotype), 149-182 (six paratypes). No differences between females and males in body size.

Integument (Figs. 1-6, 10-12, 16, 19). Body color light brownish. Body and leg surface densely microfoveolate (diameter of foveoles less than 1). In addition, prodorsum, notogaster, anogenital 


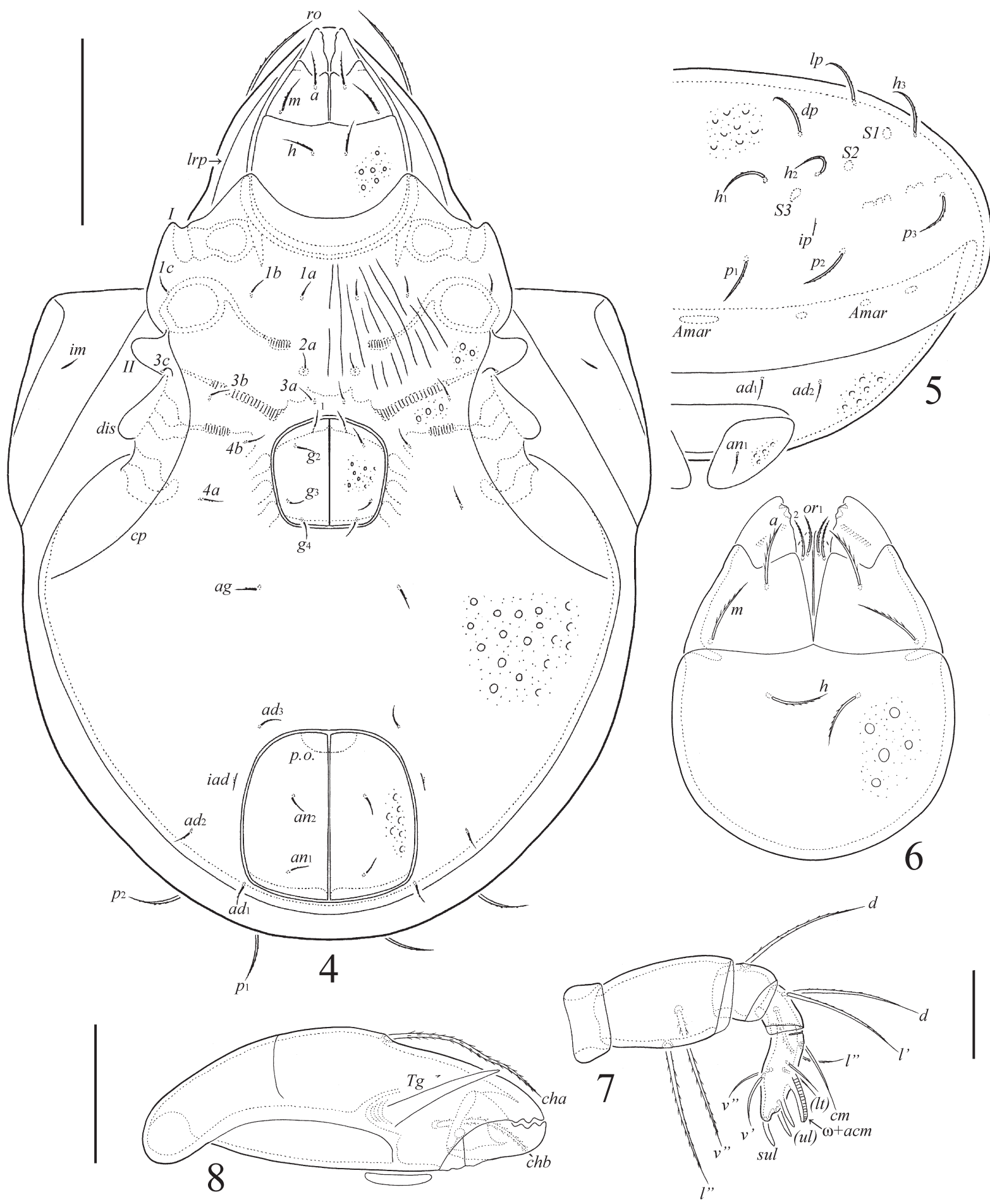

Figs. 4-8. Peloribates roynortoni Ermilov, Shtanchaeva et Subías sp.n., adult: 4—ventral view (legs not shown); 5posterior view (left half not shown); 6-subcapitulum, ventral view; 7-palp, left, paraxial view; 8-chelicera, left, paraxial view. Scale bars $=50 \mu \mathrm{m}(4,5), 20 \mu \mathrm{m}(6,8), 10 \mu \mathrm{m}(7)$.

region, subcapitular mentum, genital and anal plates, lateral parts of epimeral region, and antiaxial side of all femora and trochanters III, IV sparsely macrofoveolate (diameter of foveoles up to 4); epimeres longitudinally striate; paraxial side of all femora transversely striate.
Prodorsum (Figs. 1, 3, 12-15). Rostrum usually slightly protruding, narrowly rounded. Lamellae $1 / 2$ the length of prodorsum (measured in lateral view), with indistinctly developed lateral tooth distally. Prolamellae present, thin, lineate, reaching rostrum. Sublamellae about $1 / 2$ the length of lamel- 


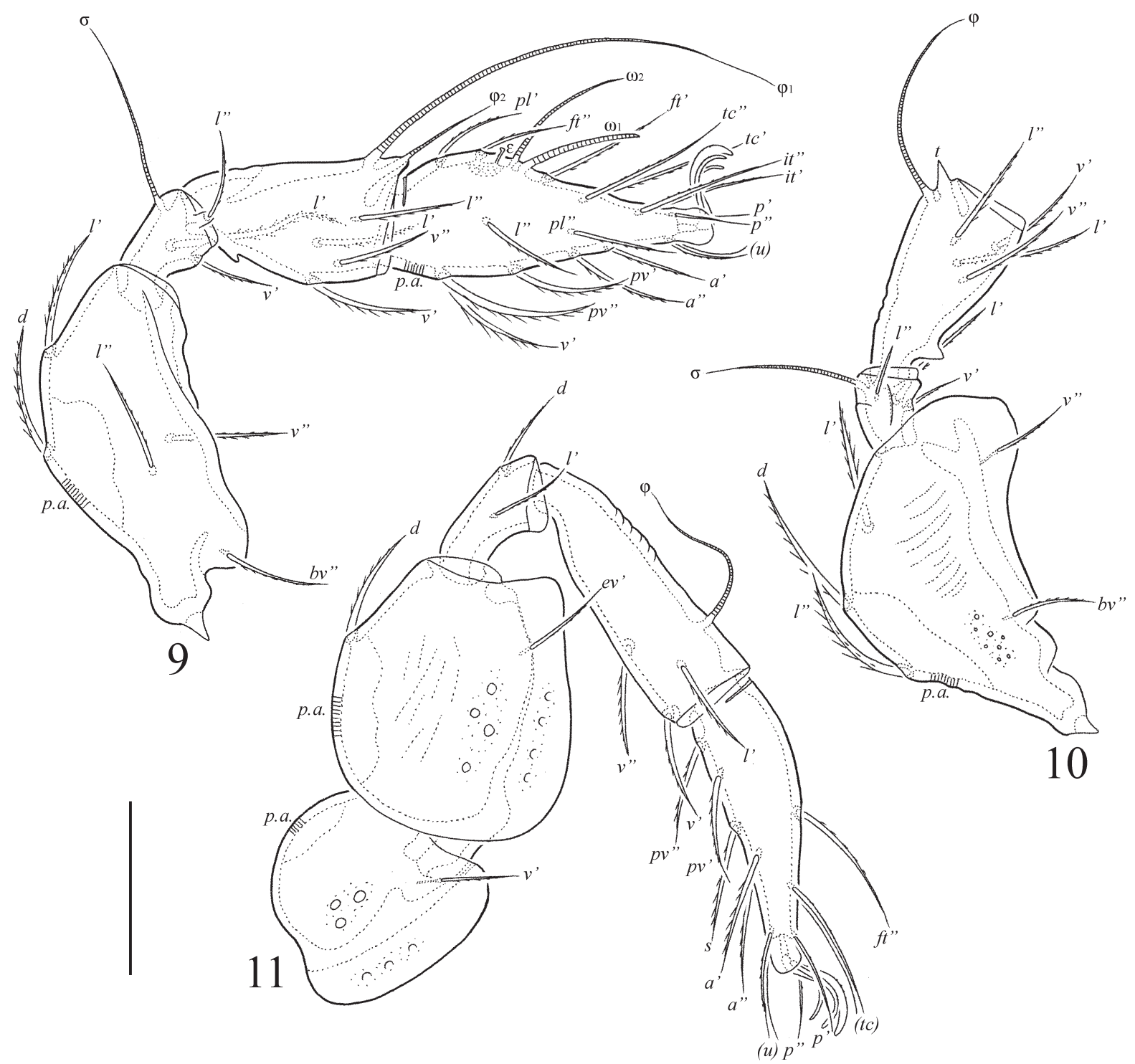

Figs. 9-11. Peloribates roynortoni Ermilov, Shtanchaeva et Subías sp.n., adult: 9-leg I, without trochanter, right, antiaxial view; $10-$ femur, genu and tibia of leg II, right, antiaxial view; $11-\operatorname{leg} \mathrm{IV}$, left, antiaxial view. Scale bar=20 $\mu \mathrm{m}$.

lae, lineate. Sublamellar porose areas (4-6) rounded, located posterior to sublamellae. Tutoria longer than lamellae, ridge-like. Rostral (24-28) and lamellar (32-34) setae setiform, barbed, directed anteromedially; ro inserted on tutorial ends, $l e$ on lamellar ends. Interlamellar setae (22-24) setiform, barbed, directed upwards. Bothridial setae (41-45) clavate, with long stalk and short, oval, shortly ciliate head. Exobothridial setae (8-10) setiform, thin, barbed. Sejugal porose areas (2-4) slightly visible, rounded, located posterolateral to interlamellar setae. Lateral prodorsal ridges distinct.

Notogaster (Figs. 1-5, 16, 17). Anterior notogastral margin slightly protruding medially. Pteromorphs triangular, rounded laterally, with distinct hinges. Fourteen pairs of notogastral setae of me- dium size (16-18), setiform, slightly or distinctly curved, barbed. Four pairs of saccules with short openings and drop-like or slightly elongate channels. Notogastral lyrifissures, opisthonotal gland openings and circumgastric sigillar band distinct. Circumgastric scissure not visible.

Gnathosoma (Figs. 4, 6-8). Subcapitulum size: 55-57×41-45. Subcapitular setae $(a, 10-12 ; m$, $12-14 ; h, 8-10)$ setiform, barbed. Adoral setae (6) setiform, heavily barbed. Length of palps: 36-41. Palpal setal formula: 0-2-1-3-9(+1 solenidion). Solenidion of palptarsi short, bacilliform (sometimes indistinctly dilated distally), connected to acm. Postpalpal setae (2) spiniform, smooth. Length of chelicerae: 57-61. Cheliceral setae setiform, barbed, cha (26-28) longer than chb 


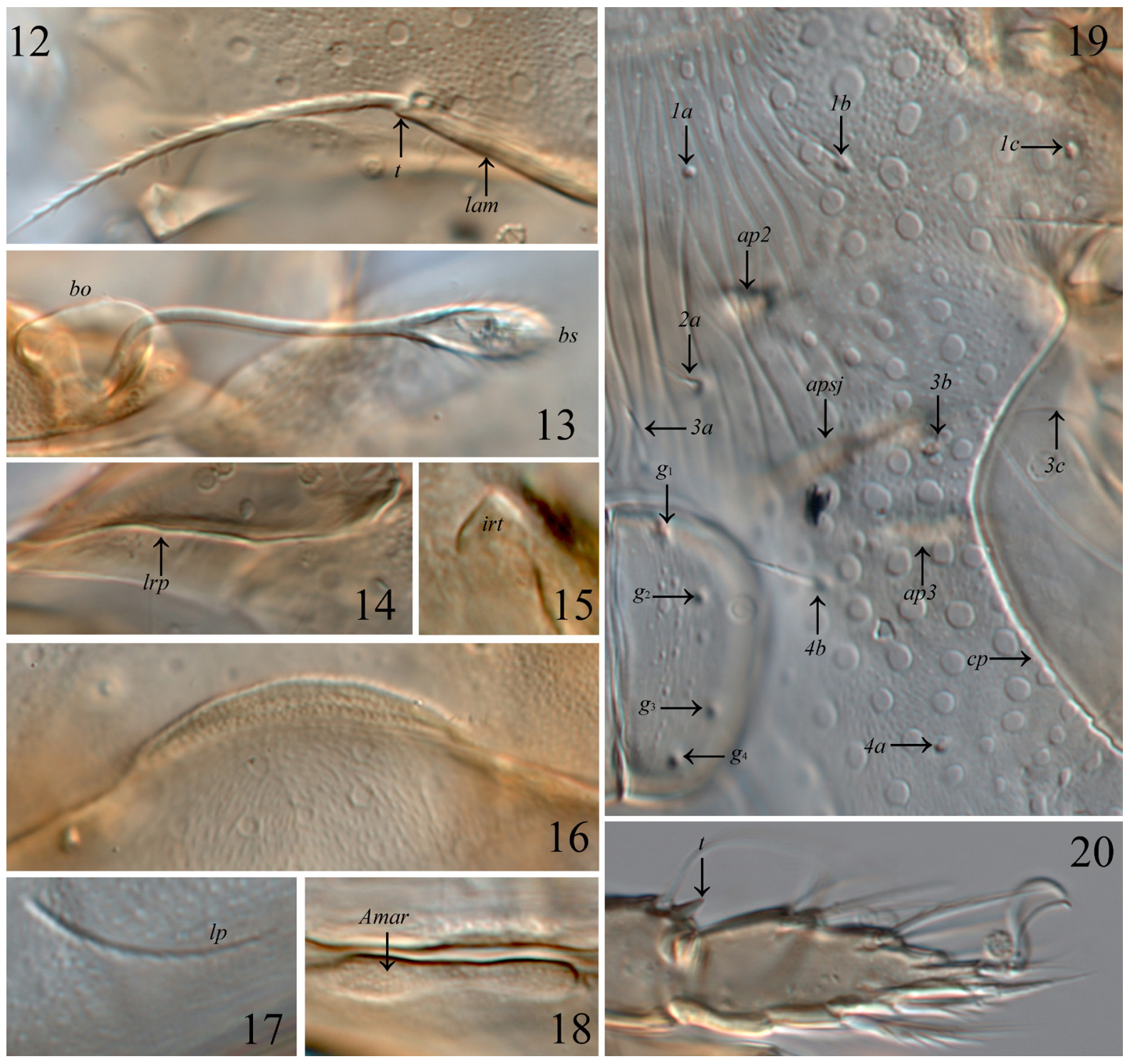

Figs. 12-20. Peloribates roynortoni Ermilov, Shtanchaeva et Subías sp.n., adult, microscope images: 12-rostral seta and distal part of lamella; 13 - bothridium and bothridial seta; 14 -lateral ridge of prodorsum; 15 - inner rostral tooth; 16 - anterior margin of notogaster; 17—notogastral seta; 18 - marginal porose area; 19 — part of epimeral and genital regions; 20 - tarsus and anterior part of tibia of leg II.

(16-18). Trägårdh's organ of chelicerae elongate triangular.

Epimeral and lateral podosomal regions (Figs. 3, 4, 19). Epimeral setal formula: 3-1-3-2. Epimeral setae setiform, slightly barbed; $3 c(6-8)$ longer than others (4-6). Pedotecta II rounded apically. Circumpedal carinae long, directed to pedotecta II. Discidia tubercle-like.

Anogenital region (Figs. 2-5, 18). Four pairs of genital, one pair of aggenital, two pairs of anal and three pairs of adanal setae short (4-6), setiform, slightly barbed. Adanal setae $a d_{1}$ posterolateral, $a d_{2}$ lateral, $a d_{3}$ preanal to anal aperture. Adanal lyrifissures located close and parallel to anal plates.
Marginal porose area represented by several parts (one part unpaired, elongate oval, located posteriorly; other several parts paired, rounded, located posterolaterally).

Legs (Figs. 9-11, 20). Tridactylous. Median claw thicker than lateral claws, all slightly barbed on dorsal sides. Tibiae I, II with posteroventral tooth. Tibiae II with anterodorsal tooth. All femora rounded anteroventrally. Porose areas on all femora and on trochanters III and IV clearly visible. Porose areas on tarsi I, II ventrobasally indistinctly visible. Formulas of leg setation and solenidia: I (1-5-3-4-19[?]) [1-2-2], II (1-5-3-4-15) [11-2], III (2-3-1-3-15) [1-1-0], IV (1-2-2-3-12) 
[0-1-0]; homology of setae and solenidia indicated in Table 1. Famulus of tarsi I short, erect, slightly dilated distally, inserted posterior to solenidion $\omega_{2}$. We could not find seta $s$ on leg tarsi I in the dissected specimens. Usually this seta simple (setiform, smooth), located between setae $u$ and $a$ in representatives of Peloribates (e.g., Beck 1964; Ermilov and Anichkin 2014). Seta $s$ is a fundamental (Norton 1977), therefore, most likely, it is also present in the new species.

Material examined. Type material. Holotype (male) and six paratypes (four females and two males): USA, Louisiana, Fountainbleau State Park (Mandeville), forest with oaks and pines, leaf litter, 18.IV.1979 (A. Grant).

Additional material. One specimen (female): USA, Texas, Tyler County, $6.73 \mathrm{~km}$ east of Warren, on FM 1943 road, $0.48 \mathrm{~km}$ south of road, 18. VIII.1979 (S.P. Lewis). One specimen (female): same, but $3.05 \mathrm{~km}$ south of road, 22.III.1980. The habitat does not appear on the slides.

Deposition. Type material. The holotype will be deposited in the mite collection of the Smithsonian Institution, National Museum of Natural History (Washington, DC), currently with the US Department of Agriculture (Beltsville, Maryland); six paratypes are deposited in the collection of the Tyumen State University Museum of Zoology (Tyumen, Russia). All in ethanol with a drop of glycerol. Additional material. Two specimens (two slides) are in the personal collection of Roy A. Norton (State University of New York, Syracuse, USA).

Etymology. The species name is dedicated to the well-known American acarologist, Prof. Roy A. Norton (State University of New York, College of Environmental Science and Forestry, Syracuse, NY, USA), for his extensive and invaluable contributions to our knowledge of mites.

Remarks. Based on the presence of four pairs of genital setae and an anterodorsal tooth on leg tibiae II, we place Peloribates roynortoni Ermilov, Shtanchaeva et Subías sp.n. in the monotypic subgenus Peloribates (Peloribatodes). The morphological traits listed above support the subgeneric status. This subgenus was described by Mahunka (2011) with Peloribates (Peloribatodes) incompatibilis Mahunka, 2011 as type species from Madagascar. The new species clearly differs from the latter by the presence of prolamellae (vs. absent), macrofoveolate prodorsum, notogaster and anogenital region (vs. not macrofoveolate) as well as striate epimeres (vs. not striate).
However, the subgeneric status of Peloribates (Peloribatodes) is problematic because its distinctive morphological traits are not accurate. Firstly, the presence of four pairs of genital setae is known in some representatives of the nominative subgenus (e.g., Peloribates europaeus Willmann, 1935; Peloribates perezinigoi Shtanchaeva, Grikurova et Subías, 2011). Secondly, the presence of the anterodorsal tibial tooth is known in some representatives of Haplozetidae (e.g., Haplozetes minimicoma, Beck, 1964; Haplozetes valbehanae Ermilov, 2017). Therefore, it could be a specific (vs. subgeneric) trait. Also, the presence or absence of tibial tooth cannot be confirmed for many species of Peloribates because the original descriptions often lack figures of legs. Hence, an additional taxonomic investigation of the subgeneric system in Peloribates is necessary in the future.

\section{ACKNOWLEDGEMENTS}

We cordially thank Prof. Dr. Roy A. Norton (State University of New York, Syracuse, USA) who kindly provided the material (Peloribates roynortoni sp.n.) for our study.

\section{REFERENCES}

Beck, L. 1964. Beiträge zur Kenntnis der neotropischen Oribatidenfauna 4. Haplozetes und Peloribates (Arach., Acari). Senckenbergiana Biologica, 45 (2): 161-183.

Berlese, A. 1908. Elenco di generi e specie nuovi di Acari. Redia, 5: 1-15.

Ermilov, S.G. and Anichkin, A.E. 2014. Taxonomic study of oribatid mites (Acari, Oribatida) of Bi Dup-Nui Ba National Park (southern Vietnam). Zootaxa, 3834 (1): 1-86.

Mahunka, S. 2011. New and little known oribatid mites from Madagascar (Acari: Oribatida), III. Opuscula Zoologica Budapest, 42 (1): 43-66.

Marshall, V.G., Reeves, R.M. and Norton, R.A. 1987. Catalogue of the Oribatida (Acari) of Continental United States and Canada. Memoirs of the Entomological Society of Canada, 139: 1-418.

Norton, R.A. 1977. A review of F. Grandjean's system of leg chaetotaxy in the Oribatei (Acari) and its application to the family Damaeidae. In: D.L. Dindal (Ed.). Biology of oribatid mites. Syracuse, SUNY College of Environmental Science and Forestry, pp. 33-61.

Norton, R.A. and Behan-Pelletier, V.M. 2009. Suborder Oribatida. Chapter 15. In: G.W. Krantz and D.E. Walter (Eds.). A Manual of Acarology. Lubbock, Texas Tech University Press, pp. 430-564. 
Subías, L.S. 2019. Listado sistemático, sinonímico y biogeográfico de los ácaros oribátidos (Acariformes: Oribatida) del mundo (excepto fósiles). Online version accessed in March 2019, 536 pp. http://bba.bioucm.es/cont/docs/RO_1.pdf
Travé, J. and Vachon, M. 1975. François Grandjean. 1882-1975 (Notice biographique et bibliographique). Acarologia, 17 (1): 1-19.

Table 1

Leg setation and solenidia of adult Peloribates roynortoni Ermilov, Shtanchaeva et Subías sp.n.

\begin{tabular}{|l|l|l|l|l|l|}
\hline Leg & $\boldsymbol{T r}$ & $\boldsymbol{F e}$ & $\boldsymbol{G e}$ & $\boldsymbol{T i}$ & $\boldsymbol{T a}$ \\
\hline I & $v^{\prime}$ & $d,(l), b v^{\prime}, v^{\prime \prime}$ & $(l), v^{\prime}, \sigma$ & $(l),(v), \varphi_{1}, \varphi_{2}$ & $(f t),(t c),(i t),(p),(u),(a),(p v), v^{\prime},(p l), l^{\prime \prime}, \varepsilon, \omega_{1}, \omega_{2}$ \\
\hline II & $v^{\prime}$ & $d,(l), b v^{\prime}, v^{\prime \prime}$ & $(l), v^{\prime}, \sigma$ & $(l),(v), \varphi$ & $(f t),(t c),(i t),(p),(u),(a), s,(p v), \omega_{1}, \omega_{2}$ \\
\hline III & $v^{\prime}, l$, & $d, l^{\prime}, e v^{\prime}$ & $l^{\prime}, \sigma$ & $l^{\prime},(v), \varphi$ & $(f t),(t c),(i t),(p),(u),(a), s,(p v)$ \\
\hline IV & $v^{\prime}$ & $d, e v^{\prime}$ & $d, l$, & $l,(v), \varphi$ & $f t^{\prime},(t c),(p),(u),(a), s,(p v)$ \\
\hline
\end{tabular}

Roman letters refer to normal setae, Greek letters to solenidia (except $\varepsilon$-famulus). Single prime (') marks setae on the anterior and double prime (") — setae on the posterior side of a given leg segment. Parentheses refer to a pair of setae. 